ПОДРШКА РОДИТЕЉИМА СА ИНТЕЛЕКТУАЛНОМ ОМЕТЕНОШЋУ

Мирјана Ђорђевић, ${ }^{1}$ Марија Цвијетић ${ }^{2}$

\title{
SUPPORTING PARENTS WITH INTELLECTUAL DISABILITIES
}

Mirjana Đorđević, Marija Cvijetić

\section{Сажетак}

Број особа са интелектуалном ометеношћу у улози родитеља се повећао током последюих деценија. Ова тенденщија може се приписати променама у схватағу појма ометености исвевећемукључиваьуособаса интелектуалном ометеношћу у активности које им раније нису биле доступне. Родитељи са интелектуалном ометеношћу суочавају се са бројним проблемима који им отежавају успешно одгајање юихове деце, као што су: мањак родитељьких вештина, сиромаштво, присуство психопатологије, недостатак подрике партнера $и$ др.

Циљ рада је да укаже на значај пружања подрике родитељима са интелектуалном ометеношћу, као и на могуће програме интервенщије који могу помоћи овим родитељима да буду успешни у одгајану своје деие. Претрагом електронске базе података Конзориијум библиотеке Србије за обједиюену набавку - КоБСОН, прикупьени су и анализирани радови аутора који су обрађивали проблематику пружања подрике родитељима са интелектуалном ометеношћу.

Резултати студија које су проучавале ефикасност интервенција усмерених на унапређење вештина родитељства код особа са интелектуалном ометеношћу показују да уз одговарајућу подршку ове особе могу унапредити своја знања и вештине родительства. Наводи се и да су соиијалне мреже подрике мајкама са интелектуалном ометеношћу углавном сиромашне, а да би юихов развој могао унапредити адекватност бриге коју ове мајке пружају својој деции.

\section{Summary}

Number of persons with intellectual disabilities (ID) that are parents has increased during the last decades. This tendency can be explained by changes in understanding of the concept of disability and the growing involvement of people with ID in the activities that earlier were not available for them. Parents with ID face a number of problems that complicate successful rearing of their children: lack of parenting skills, poverty, presence of psychopathology, lack of support from partners etc.

The aim of this paper is to highlight the importance of supporting parents with ID, as well as the possible intervention programs can help these parents to be successful in raising their children. Studies that examined supporting parents with ID were collected and analyzed by researching the electronic data base of KoBSON (Serbian Library Consortium for Coordinated Acquisition).

The results of studies that examined the effectiveness of interventions aimed at improving parenting skills in people with ID show that parents with ID can enhance their knowledge and parenting skills, when receiving appropriate support. It is also alleged that social support network for mothers with ID are mostly poor and that their development could improve the appropriateness of care provided by the mother to her children.

In order to overcome many difficulties that parents with ID face, it is necessary to provide an appropriate support that will help them to be successful in raising their children.

\footnotetext{
${ }^{1}$ Мирјана Ђорђевић, Универзитет у Београду - Факултет за специјалну едукацију и рехабилитацију.

${ }^{2}$ Марија Цвијетић, студент мастер студија, Универзитет у Београду - Факултет за специјалну едукацију и рехабилитацију.
} 
У цุиьу превазилажења бројних тешкоћа са којима се родитељи са интелектуалном ометеношћу сусрећу, неопходно је обезбедити им одговарајућу подршку како би били успешни у одгајању своје деце. Адекватна подршка могла би предупредити негативне исходе код деце ових родитеља и променити честу праксу измештања ове деце из нихове биолошке породице.

Кључнеречи:родитељи,интелектуална ометеност, подрика, интервенција.
Adequate support could prevent negative outcomes for children of these parents and change often practice of relocation of these children from their biological families.

Key words: parents, intellectual disability, support, intervention.

\section{УВОД}

Б рој особа са интелектуалном ометеношћу (у даљем тексту ИО) у улози родитеља се повећао током последњих деценија. Ова тенденција може се приписати променама у схватању појма ометености и све већем укључивању особа са ИО у активности које им раније нису биле доступне. Ипак, ставови о заснивању породица и подизању деце од стране особа са ИО нису јединствени. Већина аргумената против родитељства особа са ИО потиче из еугеничког покрета, док се аргументи за право на родитељство ових особа ослањају на декларације о људским правима и филозофију „нормализације“. ${ }^{1}$ Конвенција УН о правима особа са ометеношћу усвојена на Генералној скупштини у децембру 2006. године потврђује права ових особа да се венчавају и заснивају продице (члан 23 (1)) и предвиђа одговарајућу помоћ особама са ометеношћу у активностима подизања детета (члан 23 (2)). ${ }^{2}$ Бронфенбренерова филозофија „нормализације“, између осталог, предвиђа и деинституционализацију особа са ИО и њихово учествовање у животним активностима попут особа типичне популације, што самим тим отвара и могућности ових особа за заснивање породица, као и подизања сопствене деце.

Ипак, јавили су се бројни проблеми и сумње у вези са способношћу ових особа да буду адекватни родитељи. Иницијална истраживања су показала да су деца родитеља са ИО под ризиком за занемаривање, развојна кашњења и проблеме у понашању ${ }^{3}$, као и да постоји висок ризик за одузимање деце овим родитељима. ${ }^{4}$ Студије спроведене у развијеним државама Европе показују да између 30 и $45 \%$ родитеља са ИО не живи са својим децом. ${ }^{2}$ Такође, показало се да родитељи са ИО обично имају мањак родитељских вештина, али и друге проблеме, као што су сиромаштво, присуство психопатологије, историја злостављања или тренутно злостављање, недостатак социјалне подршке, што све заједно може неповољно утицати на капацитет родитеља да адекватно подижу децу. ${ }^{5}$ Издвојени су и бројни фактори који могу утицати на успешност родитеља са ИО, а неки од њих су: величина породице, карактеристике супружника, брачни односи, проширена породица, социоекономски фактори, коефицијент интелигенције или ниво тешкоћа у учењу; институционална историја мајке, емоционално и психичко здравље родитеља. ${ }^{1}$

Недостатак универзалне дефиниције „доброг родитеља“" често доводи до тога да професионалци доносе субјективне судове о томе да ли је родитељство ових особа довољно добро. ${ }^{6}$ Овакав вид процене могао би бити неповољан за родитеље са ИО, због предрасуда које имају неки професионалци 
о способностима ових родитеља и које би могле да утичу на њихову процену. У једној студији аутори указују на постојање четири „мита“ који се односе на родитеље са тешкоћама у учењу: прво, да ће сваки потомак ових родитеља бити особа са ометеношћу; друго, да ће ови родитељи имати прекомеран број деце; треће, да они неће бити адекватни родитељи и четврто, да они нису у стању да науче адекватне вештине родитељства. Ови митови оповргнути су резултатима бројних истраживања. ${ }^{1}$ До промена у односу према родитељству особа са ИО долази са развојем социјалног модела ометености. Према овом моделу, нагласак се премешта са личне компетенције родитеља са ИО за подизање њихове деце, на подршку коју је потребно пружити овим родитељима како би они били успешни у тој улози. Генерално, истраживања показују да су родитељи са ИО хетерогена група, и да показују варијабилност у вештинама родитељства и околностима у којима живе, те је важно обезбедити им подршку у складу са њиховим јединственим потребама. ${ }^{7}$

Међутим, показало се да различити сервиси често нису у могућности да родитељима са ИО пруже адекватну подршку због финансијских ограничења, али и недовољног разумевања индивидуалних потреба родитеља од стране стручњака. ${ }^{8}$ Многи провајдери услуга у овој области наводе да им недостају неопходне вештине, тренинг и самоувереност да ефикасно раде са овим родитељима. ${ }^{9}$ Као отежавајући фактор успешног рада јавља се и песимизам пружаоца услуга у вези са способностима ових особа да уче и превазиђу тешкоће родитељства. ${ }^{9}$

\section{МЕТОДОЛОГИЈА}

Увид у доступну литературу извршен је преко Sciindex-a (Српски цитатни индекс) и КоБСОН-а (Конзорцијум библиотека Србије за обједињену набавку), прегледом електронских база података (Wiley Interscience, Sage Pubishing, Springer, Sci- ence Direct, EBSCO). Приликом претраге коришћене су следеће кључне речи: parents, intellectual disability, support, intervention.

Претрага је вршена и према референцама које су пронађене у издвојеним радовима. Обухваћени су радови који су објављени до 2013. године, на енглеском или српском језику, у којима је обрађивана проблематика пружања подршке родитељима са ИО.

\section{ЦИЛ}

Циљ рада је да се укаже на значај пружања подршке родитељима са ИО, као и на могуће програме интервенције који могу помоћи овим родитељима да буду успешни у одгајању своје деце.

\section{ПРЕГЛЕД ИСТРАЖИВАЫА}

Ране студије у оквиру којих је проучавана проблематика родитељства особа са ИО углавном су резултирале идејом о неадекватности ових родитеља, док су скорашње студије усмерене на оно што особе са ИО могу и на програме којима се могу унапредити њихове родитељске вештине. Ови програми су углавном усмерени на одређене аспекте родитељства као што су: брига о детету, вештине везане за здравље и безбедност, доношење одлука/решавање проблема и тренинг социјалних вештина. Неретко се догађа да се програми подршке родитељима са ИО примењују тек након што се појави развојно заостајање или злостављање и занемаривање код њихове деце. $^{1}$

Један од првих прегледа студија које су се бавиле програмима интервенција код родитеља са ИО обухвата 20 студија објављених од 1983. до 1994. године, у којима је учествовало 190 родитеља са ИО, од чега 188 мајки и 2 оца, чији се количник интелигенције кретао између 50 и 79. Предмет истраживања ових студија односио се на процену ефикасности интервенција усмерених на развој вештина родитељства. Тренинзи су се углавном 
фокусирали на базичну бригу о детету, безбедност, решавање проблема, позитивне интеракције родитељ-дете и управљање дечјим понашањем. Најчешћи приступ је био бихевиорални (анализа задатка, моделовање, повратна информација, поткрепљење). Три студије у оквиру овог прегледа поредиле су групе са примењеним тренингом и без њега, и пронашле су значајне разлике између група у циљним понашањима родитеља у корист прве групе. Резултати студија у оквиру овог прегледа показују да је највећи део родитеља показао напредак у једној или више вештина. Када je у питању одржавање вештина, што је испитивало 15 студија, побољшања су се задржала код 92\% родитеља и за $55 \%$ претходно усвојених вештина. Пет студија које су садржале податке о генерализацији проналазе да је генерализација вештина присутна код 14 од 19 родитеља, али за само $21 \%$ вештина. Када су упоређене вештине родитељства особа са ИО и особа из типичне популације, чиме се бавило десет студија, није пронађена значајна разлика између резултата, док је таква разлика пре интервенције забележена. У овом прегледу Фелдман закључује да родитељи са ИО, уз одговарајући тренинг, могу да усвоје адекватне вештине родитељства. Он истиче да су интервенције најефикасније када се спроводе код куће (на месту на којем ће бити коришћене), када су усмерене на одређене, конкретне вештине и користе бихевиоралне стратегије подучавања, као што су моделовање, анализа задатака (разлагање комплексних задатака бриге о деци на кораке који се уче појединачно), давање повратне информације и награђивање. Наводи и да родитељи треба да имају много прилика да увежбавају вештине, а да повремени тренинзи одржавања вештине могу бити корисни, нарочито уколико се околности промене или је потребно вештину применити на другачији начин. ${ }^{5}$

У једној студији, која је обухватала 45 родитеља са ИО, од чега 40 мајки и 5 очева, испитивани су ефекти програма који је био усмерен на унапређење знања ових родитеља у вези са здрављем детета и безбедношћу њиховог дома. Интервенција се састојала од десет лекција које су родитељи савладавали из припремљених брошура уз помоћ едукатора који их је посећивао једном недељно у њиховом дому. Поред групе за интервенцију, постојале су и три контролне групе: група без интервенције, група која је имала брошуре, али не и помоћ едукатора и група којој је едукатор долазио у неформалне посете. Интервенција је довела до напретка способности родитеља да препознају опасности у кући и дошло је до значајног пораста броја мера предострожности које су родитељи применили у дому. Такође, значајно је унапређено препознавање симптома болести, као и знање и вештине потребне за реаговање у животно опасним ситуацијама и како безбедно користити лекове. Сва усвојена знања одржала су се и након три месеца. Овакви ефекти нису запажени код контролних група. Аутори наводе да је ова интервенција била ефикасна без обзира на здравствени статус, писменост и ниво интелигенције родитеља. ${ }^{9}$

Многе мајке са тешкоћама у учењу имају потешкоће у планирању бриге о детету када се потребе детета мењају и када је неопходно наћи алтернативна решења. У истраживању у коме је примењен програм усмерен на унапређење способности доношења одлука код ових мајки, уз коришћење вињета са ситуацијама бриге о деци, пронађено је да мајке са ИО могу да науче и примене основне кораке у процесу доношења одлука. ${ }^{1}$

Вејдова и сарадници дају преглед седам студија које су се бавиле ефектима бихевиоралних интервенција усмерених на овладавање базичним вештинама бриге о деци и њиховом здрављу и безбедности код родитеља са ИО у кућном окружењу. Све студије примениле су стратегије подучавања за које је потврђено да су ефикасне у раду са родитељима са ИО (бихевиоралне 
стратегије - анализа задатка, моделовање и понављано увежбавање). У свим студијама тренинг се спроводио у кућним условима, при чему је интервенција била редовна, једном или два пута недељно. Резултати ових студија показују да родитељи са ИО могу да науче одабране вештине родитељства. Већина студија саопштава краткорочно до средњерочног одржавања ових вештина (између једног месеца и једне године), док су налази у вези са генерализацијом били мање конзистентни. ${ }^{7}$

Нешто другачији приступ од претходно наведених користио је Фелдман, који је испитивао ефикасност самоусмереног учења (учења путем самоинструктивних аудитивних и визуелних материјала) у усвајању основних вештина бриге о деци, о њиховом здрављу и безбедности, код родитеља са ИО. У истраживању је учествовало 33 родитеља (30 мајки и три оца), просечне старости 26,3 година, чија деца су била узраста од 2 до 51 месеца (у просеку 9,9 месеци). Ниво усвојености вештина пре интервенције процењен је чек-листом која је садржала списак базичних активности бриге о деци, о њиховом здрављу и безбедности, након чега су родитељи добили материјале за самоинструирајуће учење. За родитеље који су овладали читањем обезбеђени су приручници са сликама и кратким вербалним описима важних корака у обављању сваке одабране активности бриге о деци. Други приручник односио се на безбедност у кући и састојао се од приказа опасних ситуација за дете и правилног поступања у отклањању опасности, док је трећи садржао слике различитих медицинских стања деце на којима је написано „Звати лекара“ или „Звати 911“. За родитеље који не читају, уз сликовне приручнике обезбеђене су и аудио-касете, на којима женски глас лагано чита садржаје написане у сваком приручнику. Након заједничког анализирања приручника и добијања упутстава о њиховом коришћењу, од родитеља се очекивало да самостално увежбавају вештине. Родитељи су посећивани једном недељно у циљу провере њиховог напредовања. Већина родитеља је брзо научила како да користи приручнике и аудио-касете. Процена усвојености вештина извршена је путем опсервације понашања родитеља током активности бриге о детету. Такође је испитана безбедност саме куће, а усвојеност адекватних облика понашања приликом јављања хитних медицинских потреба код деце је процењена кроз разговор са родитељима. Резултати су показали да само два родитеља нису усвојила ниједну вештину, а да је троје родитеља успело да савлада вештине уз додатну помоћ аудиокасете, док им само са приручником то није пошло за руком. Родитељи са ИО су савладали укупно 96\% одабраних вештина, а проценат коректног извођења вештине био је у значајној позитивној корелацији са вештином читања родитеља и иницијалним нивоом прихватања материјала. Усвојено понашање се одржало у просеку 7 месеци и већина родитеља је саопштавала да им приручник више није потребан. ${ }^{10}$ Наводе се и бројне предности оваквог начина учења, а неке од њих су: јефтино је, лако доступно, повећава независност родитеља са ИО, елиминише потребу за интензивним тренингом од стране специјално обученог едукатора за родитеље. Такође, родитељи могу задржати материјале као трајну помоћ која ће подстаћи генерализацију и одржавање вештина, а доживљено искуство успеха може имати позитиван утицај на мотивацију родитеља, њихово самопоуздање и веру у себе. ${ }^{10}$

За разлику од већине аутора који се баве интервенцијама ,један на један“ код родитеља са ИО, Лаура Хајнц и Петер Грант у својој студији испитују ефекте групног програма који је усклађен са потребама учесника и темама које они предложе и фокусиран на групно учење. Као предности групног програма за родитеље наводи се то што они не само да потпомажу усвајање вештина родитељства, већ и омогућују учесницима да се социјализују и учествују у дискусијама са другим родитељима ван 
свог кућног окружења. ${ }^{3}$ Њихов програм, под називом Родитељи заувек (Parents Forever), подразумева да у супортивном (удобном) окружењу водитељи уче родитеље вештинама родитељства. У овом програму учествовало је 34 родитеља са ИО, којима је био обезбеђен транспорт до места где су се тренинзи одржавали, брига о њиховој деци за време тренинга, храна и пиће током пауза и др. У улози водитеља биле су медицинске сестре и социјални радници, који су пре почетка програма имали обуку о раду са овим родитељима и били им доступни за помоћ током целе недеље. Резултати показују да су родитељи успели да науче вештине родитељства и бриге о себи. Поред тога, овај програм је био успешан у привлачењу и задржавању родитеља што је у супротности са налазима многих других студијама.

Када су у питању фактори који утичу на могућност усвајања вештина код родитеља са ИО, резултати студија су показали да мајке које спорије напредују у усвајању вештина или их слабо одржавају углавном имају додатне проблеме као што су депресија, алкохолизам, проблеми физичког здравља, недостатка подршке партнера, хаотична ситуација у кући, или њихови партнери имају проблеме са менталним здрављем. ${ }^{7}$ Упоредо са истраживањима која су имала за циљ да испитају могућности унапређења вештина родитељства код особа са ИО, повећава се и број студија чији су аутори усмерили своју пажњу на мреже друштвене подршке мајкама са ИО, под претпоставком да оне могу бити од значаја за успешније одгајање њихове деце.

У једној од њих Крос је са сарадницима испитивао социјалне мреже подршке 15 мајки са ИО, при чему се показало да је просечан број контаката мањи од седам по мајци. Аутори закључују да је тај број значајно мањи него у општој популацији. Само једна трећина мајки имала је бар једног пријатеља. ${ }^{11}$
У још једном истраживању, са сличном проблематиком, узорак је чинило 17 мајки деце предшколског узраста. Подаци су прикупљени применом интервјуа у коме су мајке саопштавале о томе ко чини њихове социјалне мреже. Резултати показују да мајке са ИО које живе саме у заједници имају релативно оскудну мрежу подршке, њихове везе су краткотрајне, а једна од четири мајке нема ниједног пријатеља или комшију који за њу представља подршку. Породица је најважнији извор подршке за ове мајке, док су провајдери сервиса друга највећа група веза подршке, али те везе су кратког века и карактеришу их слаби контакти. ${ }^{12}$

Овакви резултати додатно добијају на значају ако се имају у виду студије у којима је пронађена значајна веза између стреса код мајки и социјалне подршке коју добијају.

Група канадских аутора у истраживању које је обухватило 32 мајке са ИО, чија су деца узраста од две до тринаест година, налази да у просеку ове мајке имају значајно лошије ментално и физичко здравље у поређењу са нормама типичне популације. Такође, резултати ове студије показују да постоји значајна веза између стреса мајке и стила родитељства, као и проблематичног понашања њихове деце. Добијена је и статистички значајна негативна корелација између мајчиног стреса и позитивног родитељства - виши стрес повезан са мање позитивним, а више хостилним или недоследним стилом родитељства. ${ }^{13}$

У прегледу студија које су се бавиле психолошким благостањем родитеља са ИО и социјалном подршком коју ове родитељи имају, анализирано је укупно осам студија, објављених од 1989. до 2009. године. Аутори проналазе да родитељи са ИО саопштавају мање психичко благостање него родитељи из типичне популације, а утврђена је и веза између психолошког благостања и социјалне подршке коју родитељи добијају. ${ }^{6}$

Поједине студије, чији је предмет био родитељство особа са ИО, имале су за 
циљ идентификовање фактора ризика у вези са родитељством особа са ИО. У једној од њих учествовао је 101 родитељ са ИО, са укупно сто седамдесет двоје деце. Резултати ове студије указују на то да постоје четири доминантна елемента која су значајно повезана са високим ризиком за потенцијално лош третман детета и која су разликовала родитеље „високог ризика“ са ИО од родитеља „ниског ризика“ са ИО. Висок ризик је повезан са мајкама које су: имале трауму у детињству (емоционално или физичко злостављање), имају додатне тешкоће поред ИО (физички или сензорни дефицит) и које су имале дете са ометеношћу. Повећан ризик за неадекватан третман детета повезан је са партнерима мајки када они немају ИО или када имају историју криминалних активности и/или антисоцијалног понашања (укључујући сексуалне прекршаје, насиље у породици и злоупотребу супстанци). ${ }^{14}$

У литератури се наводи неколико битних разлика између родитеља типичне популације и родитеља са ИО, који могу допринети већим тешкоћама родитеља са ИО приликом одгајања деце. Наводи се да родитељи са ИО често немају приступ могућностима да уче, што је родитељима типичне популације гарантовано. Такође, већина родитељапросечних интелектуалних способности је била изложена позитивним примерима родитељства, што није случај са многим родитељима са ИО, нарочито онима који су одрасли у институцијама. Већина родитеља без ИО има приступ популарној литератури и едукативним материјалима о трудноћи и родитељству, док родитељи са ИО имају потешкоће у разумевању и примени знања из те литературе. Поред тога, већина родитеља типичне популације има мрежу особа на које могу да рачунају, за практичну помоћ и саветовање, док родитељи са ИО имају слабије развијене мреже подршке. ${ }^{2,11,12}$ Све наведене околности могле би отежавати особама са ИО успешно преузимање и испуњавање улоге родитеља.
Када је реч о различитим врстама подршке мајкама са ИО, поједини аутори истичу да постоје две врсте подршке: прва која је усмерена на унапређење компетенција мајке и која оснажује њихов осећај компетентности, а уједно и истиче значај њихове улоге у животу детета (competence-promoting); друга врста подршке је она која инхибира компетентност мајке, критичка је, претпоставља мајчину инкомпетенцију, појачава осећање неадекватности код мајки и подрива њихову независност (competence-inhibiting). ${ }^{11}$

Фелдман истиче да многи програми подршке породици и ране интервенције нису припремљени за интензивно и дуготрајно пружање подршке, што ове породице захтевају. Показало се да едукатори обично немају широк спектар знања и вештина потребних за ефикасно обављање посла едукатора за родитеље. Ове компетенције укључују знања о развоју детета, здрављу, безбедности и храњењу, као и о ефикасним методама подучавања одраслих особа са когнитивним ограничењима. ${ }^{10}$ Стога признати стручњаци у овој области наводе низ принципа које особље које пружа подршку родитељима са ИО мора поштовати, како би њихов рад био ефикасан. У те принципе спадају: рад на основу разумевања самих родитеља о њиховој ситуацији, о њиховим приоритетима и преокупацијама; узимање у обзир контекста у коме живе, рад на малим циљевима, фокусирање на оно што родитељи могу и вредновање њихових вештина. ${ }^{8}$

У блиској вези са налазима и тумачењима Фелдмана су и резултати националне студије у Немачкој, у којој се показало да пропорционално више млађе деце живи са својим биолошким родитељима са ИО у односу на старију децу. Аутор ове студије наводи могућност да се родитељи старије деце сусрећу са више тешкоћа, али и да је професионална помоћ усмерена првенствено ка родитељима млађе деце (програми тренинга се углавном баве 
вештинама као што су хигијенске навике и стимулација језичког развоја), док се често не излази у сусрет потребама родитеља старије деце, које произилазе из промена као што су полазак детета у школу или улазак у пубертет. ${ }^{15}$

\section{ЗАКљУЧАК}

Истраживања која су проучавала ефикасност интервенција усмерених на унапређење вештина родитељства особа са ИО указују на генерално позитивне налазе. 10, 1, 9, 7 Ове студије потврђују ефикасност интервенција за усвајање и одржавање различитих знања и вештина родитељства као што су: базичне активности бриге о деци (купање, мењање пелена, храњење), здравље и безбедност у кући, интеракција родитеља и детета, доношење одлука управљање понашањем детета и др.

Као најуспешније интервенције наводе се индвидуални бихевиорални програми, али су позитивни ефекти пронађени и приликом примене групних интервенција ${ }^{3}$, као и путем самоусмереног учења. ${ }^{10}$

Резултати истраживања показују да су мајке са ИО често социјално изоловане или да имају веома сиромашне мреже социјалне подршке, које су углавном ограничене на чланове њихове породице. ${ }^{11,12}$ Овај налаз је веома важан с обзиром на пронађене значајне везе између оскудне мреже социјалне подршке и стреса кодмајки, као и везеизмеђу стреса код мајки и проблема у понашању детета. Све наведено указује на закључак да би пружање социјалне подршке могло да буде важно у унапређењу адекватности бриге коју мајке са ИО пружају својој деци.

Идентификовани су и бројни фактори који особама са ИО отежавају успешно играње улоге родитеља: проблеми физичког и психичког здравља, недостатак подршке партнера, партнер са проблемом менталног здравља, емоционално или физичко злостављање у детињству, недостатак позитивних примера родитељства, недоступност или неразумевање едукативне литературе о родитељству и др.

У циљу превазилажења бројних тешкоћа са којима се родитељи са ИО сусрећу, неопходно је обезбедити им одговарајућу подршку како би били успешни у одгајању своје деце. Такође, веома је важно да стручњаци који пружају подршку буду осетљиви на индивидуалне потребе сваког од родитеља и оспособљени да на те различите потребе одговоре. Адекватна подршка могла би предупредити негативне исходе код деце родитеља са ИО и променити честу праксу измештање ове деце из њихове биолошке породице.

\section{ЛИТЕРАТУРА}

1. Sheerin F: Parents with learning difficulties: a review of literature. J Adv Nurs 1998; 28(1): 126-133.

2. IASSID Special Interest Research Group on Parents and Parenting with Intellectual Disabilities: Parents labelled with intellectual disability: position of the IASSID SIRG on parents and parenting with intellectual disabilities. J Appl Res Intellectl Disabil 2008; 21(4): 296-307.
3. Heinz L, Grant P: A process evaluation of a parenting group for parents with intellectual disabilities. Eval Program Plann 2003; 26(3): 263-274.

4. Booth T: Parents with learning difficulties, child protection and the courts. Representing Children 2000; 13(3): 175 188.

5. Feldman M: Parenting education for parents with intellectual disabilities: a review of outcome studies. Res Develop Disabil 1994; 15(4): 299-332. 
6. Darbyshire L, Kroese B: Psychological well-being and social support for parents with intellectual disabilities: risk factors and interventions. J Pol Pract Intellect Disabil 2012; 9(1): 40-52.

7. Wade C, Llewellyn G, Matthews J: Review of parent training interventions for parents with intellectual disability. J Appl Res Intellect Disabil 2008; 21(4): 351-366.

8. Clayton O, Chester A, Mildon R, Matthews J: Practitioners who work with parents with intellectual disability: stress, coping and training Needs. J Appl Res Intellect Disabil 2008; 21(4): 367-376.

9. Llewellyn G, McConnell D, Honey A, Mayes R, Russo D: Promoting health and home safety for children of parents with intellectual disability: a randomized controlled trial. Res Develop Disabil 2003; 24(6): 405-431.

10. Feldman M: Self-Directed Learning of Child-Care Skills by Parents With Intellectual Disabilities. Infants and Young Children 2004: 1(17); 17-31.
11. Kroese SB, Hussein H, Clifford C, Ahmed N: Social support networks and psychological well-being of mothers with intellectual disabilities. J Appl Res Intellect Disabil 2002; 15(4): 324-340.

12. Llewellyn G, McConnell D: Mothers with learning difficulties and their support networks. J Intellect Disabil Res 2002; 46(1): 17-34.

13. Aunos M, Feldman M, Goupil G: Mothering with intellectual disabilities: relationship between social support, health and well-being, parenting and child behaviour outcomes. J Appl Res Intellect Disabil 2008; 21(4): 320-330.

14. McGaw S, Scully T, Pritchard C: Predicting the unpredictable? Identifying high-risk versus low-risk parents with intellectual disabilities. Child Abuse \& Neglect 2010; 34(9): 699-710.

15. Pixa-Kettner U: Parenting with intellectual disability in Germany: results of a new nationwide study. J Appl Res Intell Disabil 2008; 21(4): 315-319.

Контакт: Мирјана Ђорђевић, Универзитет у Београду - Факултет за специјалну едукацију и рехабилитацију, Високог Стевана 2, Београд; е-mail: mira.djordjevic81@gmail.com 